\title{
New Late Ordovician cornulitids from Peru
}

\author{
OLEV VINN \& JUAN CARLOS GUTIÉRREZ-MARCO
}

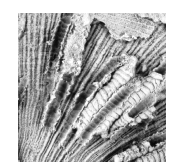

\begin{abstract}
Two new species of cornulitids, Cornulites zatoni sp. nov. and Cornulites vilcae sp. nov., are described from the lower part (Sandbian) of the Calapuja Formation of south-western Peru. Late Ordovician cornulitid diversities of Peru (Gondwana) and Estonia (Baltica) are similar. Aggregative growth form dominates among the cornulitids of the Sandbian of Peru. Multiple oriented C. zatoni sp. nov. specimens on a strophomenid brachiopod likely represent a syn vivo encrustation. Cornulitids from the Sandbian of Peru differ from those known from the Sandbian of Baltica. C. zatoni sp. nov. possibly also occurs in the Late Ordovician of Laurentia. $•$ Key words: problematic fossils, tubeworms, Sandbian, Gondwana.
\end{abstract}

VINN, O. \& GUTIÉRREZ-MARCO, J.C. 2016. New Late Ordovician cornulitids from Peru. Bulletin of Geosciences 91(1), 89-95 (2 figures). Czech Geological Survey, Prague. ISSN 1214-1119. Manuscript received November 26, 2015; accepted in revised form January 29, 2016; published online February 22, 2016; issued March 17, 2016.

Olev Vinn (corresponding author), Department of Geology, University of Tartu, Ravila 14 A, 50411 Tartu, Estonia; olev.vinn@ut.ee - Juan Carlos Gutiérrez-Marco, Instituto de Geociencias (CSIC, UCM) and Departamento de Paleontología, Facultad de Ciencias Geológicas, José Antonio Novais 12, E-28040 Madrid, Spain; jcgrapto@ucm.es

Cornulitids are mostly known as common hard substrate encrusters, and like other encrusters (Taylor \& Wilson 2003), generally retain their original position on the substrate after fossilization. They are especially common in shallow marine sediments, usually associated with carbonate platforms (Zatoń \& Borszcz 2013). Their stratigraphical importance is much less than that of their free-living relatives the tentaculitids (Bond 2006, Wittmer \& Miller 2011), but cornulitids are important paleoecologically (Richards 1974, Vinn 2010). These tubeworms are found only in normal marine sediments and they have a stratigraphical range from Middle Ordovician to Late Carboniferous (Vinn 2010). Late Ordovician cornulitids apparently gave rise to microconchids (i.e. small spirorbiform tubeworms), which could live in waters of various salinities (e.g., Zatoń et al. 2012, 2014), and were presumably direct ancestors also of free-living tentaculitids (Vinn \& Mutvei 2009, Vinn 2010).

Cornulitids had a range of ecologies, with seven adaptive strategies: (1) general hard substrate encrusters; (2) non-distorting symbiotic solitary encrusters; (3) selective endosymbionts; (4) selective distorting symbionts; (5) secondarily free solitary soft-bottom dwellers; (6) aggregative soft-bottom dwellers; and (7) symbiotic aggregative hard substrate encrusters (Vinn 2010).

Ordovician cornulitids from South America are poorly studied, with only a single paper illustrating some specimens from Peru (Chacaltana et al. 2010). The majority of studies of Ordovician cornulitids have been focused on faunas of North America (Hall 1847, 1888; Richards 1974) and Europe (Schlotheim 1820, Murchison 1854). These mostly $19^{\text {th }}$ century species are difficult to recognize in the peri-Gondwanan margin of South America and Africa.

The aims of the current paper are to: (1) systematically describe cornulitid tubeworm fossils from the Late Ordovician of Peru, and (2) discuss the diversity, ecology and palaeobiogeographical distribution of Ordovician cornulitid tubeworms.

\section{Material and methods}

Material was collected during the fieldwork in 2009 and 2013. Collected specimens were preserved as external and internal moulds. Latex casts were made from all of the collected external moulds in order to better compare the material with well-preserved cornulitid specimens from the Ordovician of North America, China and Estonia. The latex casts were whitened with $\mathrm{MgO}$ and photographed with a scale bar using a Canon EOS 5D digital camera with a Canon Compact-Macro EF $100 \mathrm{~mm}$.

The original specimens from which latex casts are made are housed in the collections of the Instituto Geológico Minero y Metalúrgico (Lima, Peru), Código Paleontológico INGEMMET (CPI) and assigned registration numbers CPI-7011 to CPI-7028. 


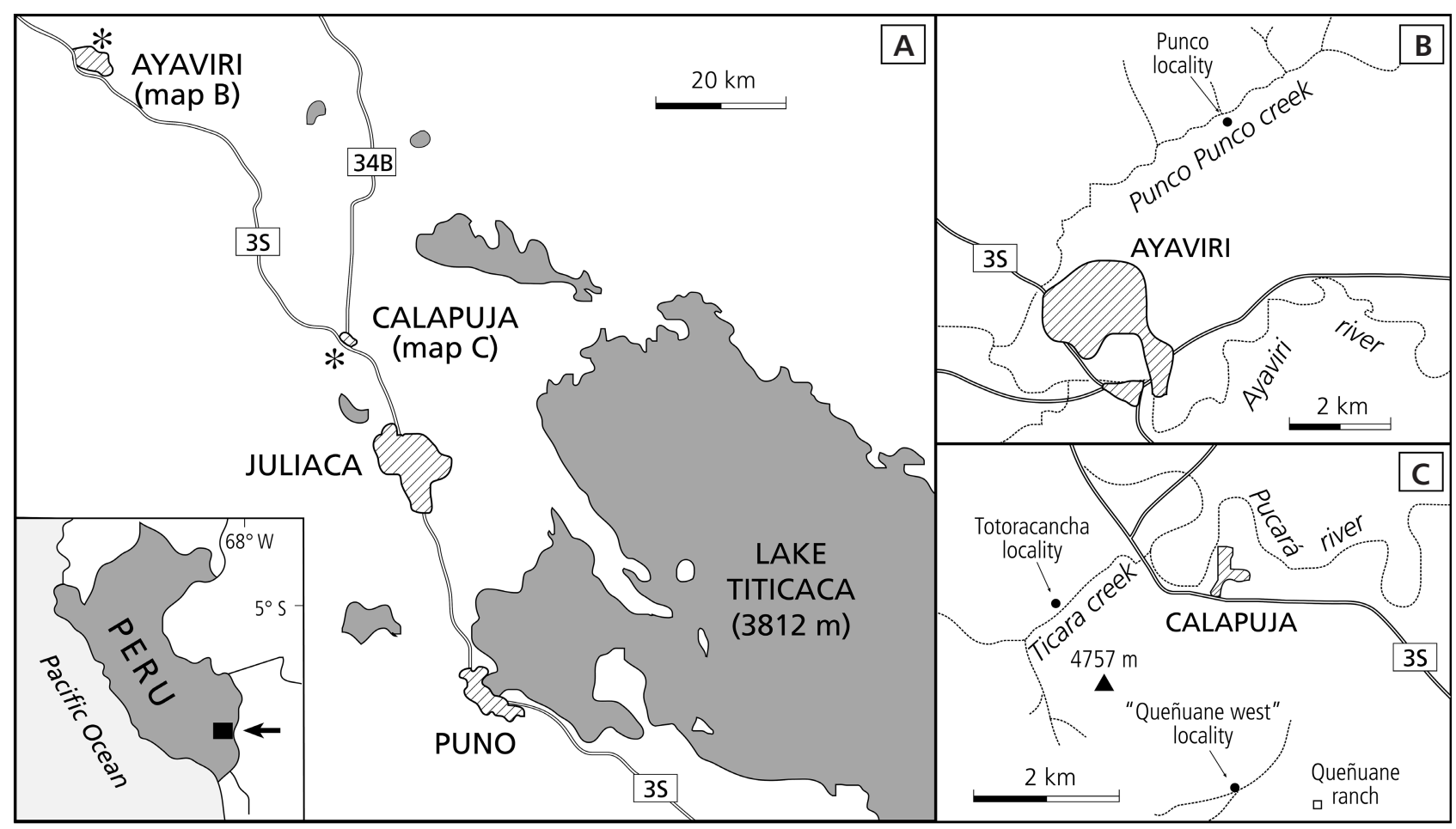

Figure 1. A-map showing the situation of the fossil localities yielding Upper Ordovician cornulitids from southeastern Peru (inset map and asterisks in A). $\bullet$ B - detail of the position of the Punco locality near Ayaviri, yielding Cornulites vilcae sp. nov. $\bullet \mathrm{C}-$ map with the Totoracancha and "Queñane west" localities near Calapuja, yielding Cornulites zatoni sp. nov.

\section{Geological background and localities}

The study area (Fig. 1) is situated ca 50-120 km northwest of Lake Titicaca in the Altiplano (high plains) of the Puno Department, southwestern Peru. This morphotectonic region is located in the northern part of the Central Andean Palaeozoic Basin, being continuous with the Bolivian Altiplano (in a south-west direction) and running southwards to reach the Puna (= Altiplano) of northwestern Argentina and north Chile.

Ordovician sedimentary rocks of the Peruvian Altiplano are assigned to the Calapuja Formation (sensu lato), a thick siliciclastic succession mainly observed in the Palaeozoic inliers of Ayaviri and Juliaca, displaying a NW-SE trend (Laubacher 1977, 1978). The Calapuja Formation sensu stricto, as revised by Klink et al. (1986) and Palacios et al. (1993), is a marine shale-sandstone succession with a maximum thickness of $4000 \mathrm{~m}$. The base and the exact age of the formation are unknown, being usually equated with the Upper Ordovician. Several fossiliferous assemblages occurring in the lower third of the Calapuja Formation have been recently reviewed by Villas et al. (2015) and placed in the upper Sandbian. North of the Ayaviri Fault, the outcrops of what was also considered to be Calapuja Formation near Ayaviri (Laubacher 1977, 1978) were recently reinterpreted as the western prolonga- tion of the Sandia Formation of the Eastern Cordillera (Díaz-Martínez et al. 2001). However the latter unit, dominated by sandstones, shows a complex stratigraphical development, more intricate than previously believed, involving diverse and probably non-correlated units from both the sedimentary and chronostratigraphical points of view (Gutiérrez-Marco et al. 2010). As the Sandbian fossil localities placed near Ayaviri that were later ascribed to the Sandia Formation by Díaz-Martínez et al. (2001) show palaeontological resemblances with those of the typical Calapuja Formation, they are provisionally placed in the latter unit.

In the present paper we have examined the cornulitids collected from three localities of the Calapuja Formation, NW of Lake Titicaca (Fig. 1). From the southern Calapuja inlier, the Totoracancha-Tilcara section provided abundant specimens, all coming from bed C3 of Villas et al. (2015, figs 1 and 2), and two more from correlative strata occurring at the "Queñuane-west" section near the Queñuane ranch, $c a 4 \mathrm{~km}$ south of Calapuja. From the Ayaviri inlier, several specimens were collected at the fossil locality "Punco creek" of Laubacher (1977, p. 38). According to the associated brachiopods and trilobites, all examined cornulitid material comes approximately from the same beds in the lower part of the Calapuja Formation (upper Sandbian). 


\section{Systematic palaeontology}

Phylum Incertae sedis

Class Tentaculitida Bouček, 1964

Order Cornulitida Bouček, 1964

Family Cornulitidae Fisher, 1962

\section{Genus Cornulites Schlotheim, 1820}

Type species. - Cornulites serpularius Schlotheim, 1820, Silurian of Gotland, Sweden.

\section{Cornulites zatoni sp. nov.} Figure 2A-D

1888 Cornulites sp. - Hall, p. 12, pl. 115, fig. 24.

2010 Cornulites sp. 2. - Chacaltana et al., p. 215, figs $1.5-1.7$.

Types. - Holotype: CPI-7013a (Fig. 2C). Paratypes: CPI-7011-7012 and 7013b to CPI-7026 (Fig. 2A-D).

Diagnosis. - Tubes small, expanding slowly to moderately rapidly in diameter. Covered externally with prominent, well-developed but irregularly shaped annulations that have sharp crests and deep interspaces; well-developed, fine longitudinal costae present.

Material. - Ninety-six moulds of tubes, mostly complete and in the form of aggregates. Some tubes are attached to the strophomenid brachiopod Colaptomena expansa expansa (Sowerby, 1839).

Locality. - Totoracancha (Chacaltana et al. 2010; Villas et al. 2015, fig. 1.B1), ca $2.5 \mathrm{~km}$ west of the town of Calapuja, Department of Puno, Peru: lat. $15^{\circ} 18^{\prime} 41.8^{\prime \prime} \mathrm{S}$, long. $70^{\circ}$ $14^{\prime} 27.9^{\prime \prime} \mathrm{W}$, alt. $3858 \mathrm{~m}$. In addition to the type locality, a single specimen of the same species (CPI-7026) comes from the "Queñuane west" locality, also in the Calapuja area (Fig. 1C).

Stratigraphy. - Fossiliferous sandstone bed rich in rhynchonelliform brachiopods, with some cornulitids, gastropods, bivalves, bryozoans, crinoids and trilobites; identified as horizon C3 in the Totoracancha-Tilcara section of Villas et al. (2015, Fig. 2). Lower part of the Calapuja Formation, $60 \mathrm{~m}$ below the base of the quartzitic unit Q3 at the stratotype section. This bed was considered as Sandbian in age by these authors, being probably equivalent to the Sa2 stage slice of Bergström et al. (2009).

Etymology. - In honour of Dr. Michał Zatoń (University of Silesia, Poland) for his thorough investigations of tentaculitoid tubeworms.
Description. - Tubes can be attached to the shells of brachiopods or form free aggregations of up to eleven tubes. Various growth stages may be present in a single aggregation. Tubes cemented to brachiopods can be oriented in parallel or lack such orientation. Tubes are small, mostly straight, but some can be curved to slightly sinuous. They are 5.0 to $20.0 \mathrm{~mm}$ long and have apertures 1.2 to $3.0 \mathrm{~mm}$ wide. The tube wall is relatively thin. Tube expanding slowly to moderately rapidly in diameter. Tube divergence angle is $6^{\circ}$ to $10^{\circ}$. Tubes covered externally with prominent well developed but irregularly shaped annulations. There are six to seven annuli per $5 \mathrm{~mm}$ of tube at a diameter of $2.5 \mathrm{~mm}$. The dimensions of annuli gradually but somewhat irregularly increase with the growth of the tube. The crests of annuli are sharp and the spaces between the annular crests are deep. Tube base is not widened at the contact with the substrate. Internal annuli are prominent and have an irregular shape; they are 0.4 to $0.5 \mathrm{~mm}$ wide at the aperture of a relatively small specimen. The tubes are externally covered by well-developed, regular and fine longitudinal costae. There are 10 to 12 costae per $1 \mathrm{~mm}$ at a tube diameter of $2.5 \mathrm{~mm}$.

Discussion. - This new species closely resembles Cornulites flexuosus (Hall 1847, p. 92, pl. 29, fig. 6, pl. 78, fig. 2) in its well-developed annulation and costae but differs in the smaller angle of tube divergence, finer costae and less regularly shaped annuli. It is also somewhat similar to the Cornulites sp. A of Vinn (2010, p. 110, fig. 6) in its relatively well developed annuli and fine costae, but differs by having less regularly shaped annuli and better developed costae. Another similar species, Cornulites annulatus (Schlotheim, 1820), also has well-developed annulations (Murchison 1854, p. 86, fig. 4), but these are less regular than in the new species.

\section{Cornulites vilcae sp. nov.}

Figures 2E, F

2010 Cornulites sp. 1. - Chacaltana et al., figs 1.3 and 4.

Types. - Holotype: CPI-7027a (Fig. 2E right). Paratypes: CPI-7027b (Fig. 2E left) and CPI-7028 (Fig. 2F).

Diagnosis. - Straight solitary large free tubes, expanded moderately in diameter, with sharp annular crests, ringlike. Interspaces between crests relatively deep and long.

Material. - Two complete external moulds and one partial external mould.

Locality. - Punco Punco creek (Laubacher 1977, p. 38), ca $4.5 \mathrm{~km}$ northwest from the city of Ayaviri, Department of 
Puno, Peru: lat. $14^{\circ} 50^{\prime} 37.9^{\prime \prime} \mathrm{S}$, long. $70^{\circ} 34^{\prime} 20.2^{\prime \prime} \mathrm{W}$, alt. $4015 \mathrm{~m}$.

Stratigraphy. - Massive sandy shales, probably late Sandbian in age, from the lower part of the ?Calapuja Formation, Late Ordovician.

Etymology. - In honor of Ms. Susana G. Vilca Achata, current director of INGEMMET (the National Geological Survey, Lima), who actively promotes palaeontological work in Peru in the frame of research on Peruvian natural heritage, and who was born in the Department of Puno in which the type locality is placed.

Description. - Solitary large free tubes. Tubes are straight and covered externally with well-developed prominent regular annuli. Annular crests sharp, ring-like, with relatively deep and long interspaces and are oriented perpendicular or slightly oblique to the longitudinal axis of the tube. Tubes are 28.0 to $29.5 \mathrm{~mm}$ long and have apertures 5.0 to $5.3 \mathrm{~mm}$ wide. Tube diameter expansion rate is moderate, with tube divergence angle $10^{\circ}$ to $11^{\circ}$. There are three annuli per $5 \mathrm{~mm}$ of tube at the diameter of $5.0 \mathrm{~mm}$. The dimensions of annuli gradually and relatively regularly increase with the growth of the tube. The internal annuli are prominent and have an irregular shape; they are 1.1 to $2.0 \mathrm{~mm}$ wide at diameter of $5.0 \mathrm{~mm}$. Tubes lack longitudinal costae and the surface of the annuli is smooth.

Discussion. - The new species is somewhat similar to Cornulites sp. A of Vinn (2010, p. 110, fig. 6) in its relatively regular annuli and long interspaces between annular crests, but differs in having sharper ring-like annular crests and deeper interspaces between the crests. It also resembles Cornulites sterlingensis (Meek \& Worthen 1865, p. 255) in its well-developed annuli but differs from this species by the lack of costae and more ring-like annular crests. The new species is similar to Cornulites scalaris (Schlotheim 1820, pl. 29, fig. 6) in its regular annulation, but differs in having less prominent annuli and a more conical shell. The new species differs from Cornulites zatoni sp. nov. in having regular annulation and larger tubes. Tube divergence angle of the new species is slightly larger than in $C$. zatoni sp. nov.

\section{Discussion}

\section{Diversity}

The presence of two species of cornulitids in the Sandbian of Peru is similar to the situation in Estonia from where two species of Cornulites with non-overlapping stratigraphical ranges have been recorded (Vinn 2013). The Katian fauna of cornulitids is richer in Baltica, where seven species occur, with a maximum of three species occurring together (Vinn 2013). Thus, Late Ordovician cornulitid diversities of Estonia (Baltica) and Peru (Gondwana) appear to be similar. North American Late Ordovician cornulitids (Hall 1847,1888 ) seem to be more diverse than faunas from Estonia and Peru. On the other hand, only one species of cornulitids is known from the Late Ordovician of South China (Zhan \& Vinn 2007). Two cornulitid species - Cornulites annulatus (Schlotheim, 1820) and Cornulites scalaris (Schlotheim, 1820) - occur in the Late Ordovician of Britain (Avalonia) (Murchison 1839), and C. scalaris was also mentioned from the Late Ordovician of Spain (Verneuil \& Barrande 1855). The cornulitid record in Bohemia (Czech Republic) is mostly restricted to Katian to Hirnantian strata (Barrande 1867), with two species first appearing in different Sandbian formations, C. confertus Barrande, 1867 and C. mescai (Prantl, 1948). From the Katian of Sardinia (Italy), six cornulitid species have been described (Meneghini 1857, Vinassa de Regny 1927, Spano 1974), all very different from the Peruvian taxa but showing some resemblance (Spano 1974) with rare Late Ordovician cornulitids known from Scotland (Cowper Reed 1923). It seems that diversity of cornulitids in the Late Ordovician was relatively low everywhere, and that many of the Late Ordovician species described from peri-Gondwanan Europe (in part originally referred to the genera Tentaculites or Conchicolites) are needed of an in-depth review.

\section{Palaeoecology}

All the studied cornulitids from the Sandbian of Peru occur in normal marine shelf sediments. However, cornulitids are usually common in shallow waters of carbonate platforms (Vinn 2013), but in the Sandbian of Peru they occur in siliciclastic deposits. Thus, early cornulitids had colonized various marine sedimentary environments by the Sandbian. The Peruvian facies were formed in shallow-water environments - coquinoid sandstones with hummocky-cross stratification in Calapuja, perhaps more quiet waters in Ayaviri - implying in both cases deposition between the fair-weather wave base and storm wave base. Thus, Late Ordovician cornulitids may have preferred shallow water environments. Most cornulitids in the Sandbian of Peru have an aggregative growth form. The secondarily free solitary forms are relatively rare, as are cornulitids attached to the brachiopods. Dominance of aggregative growth forms in the Sandbian of Peru contrasts with the situation in the Late Ordovician of Baltica where all of the cornulitids are attached to brachiopods (Vinn 2013). One could explain this by different sedimentation environments. Aggregative growth forms may have been favourable in siliciclastic basins. However, aggregation is often seen in 


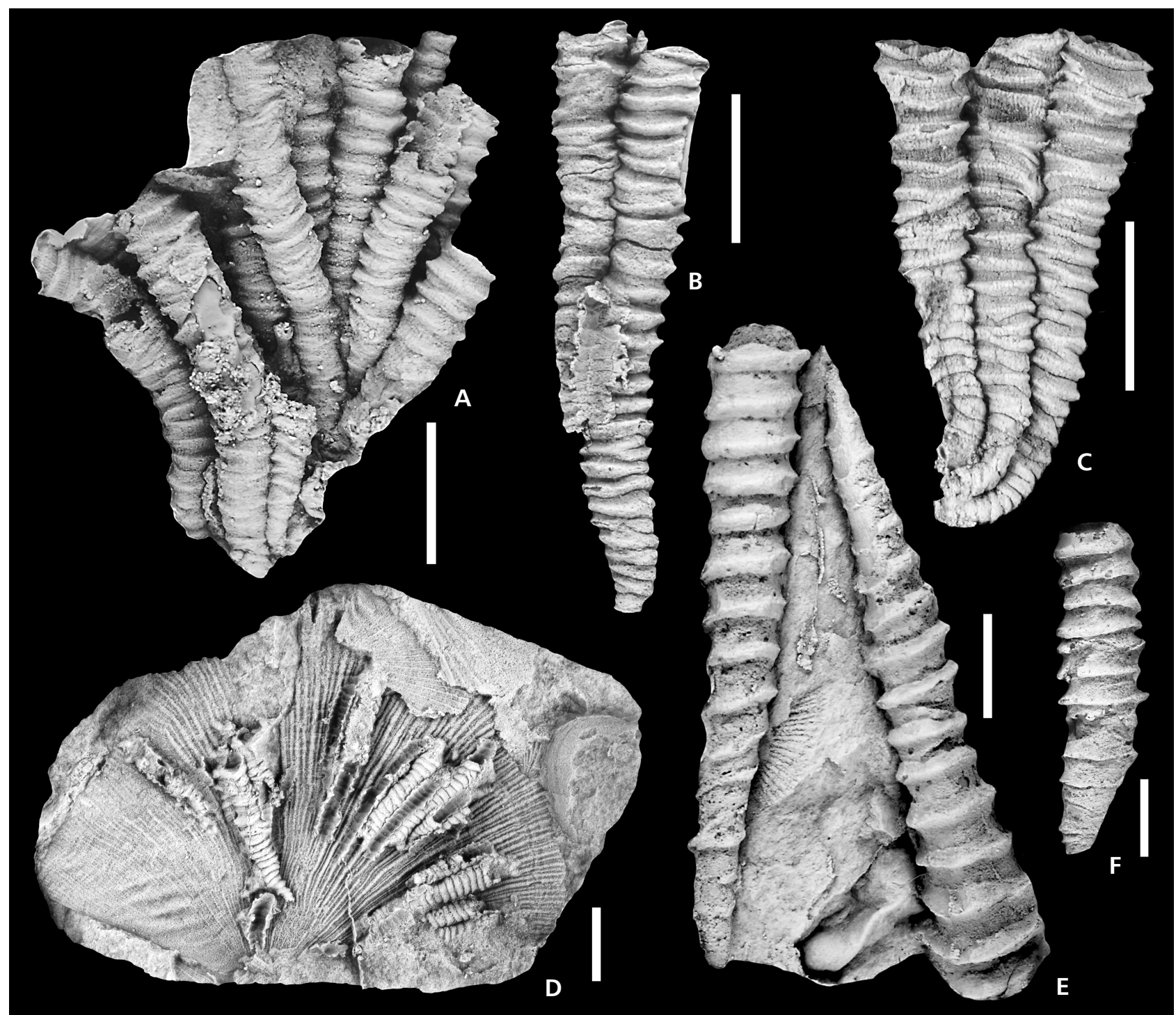

Figure 2. A-D - Cornulites zatoni sp. nov. from the Sandbian (Calapuja Formation) of Totoracancha, ca $2.5 \mathrm{~km}$ west of the town of Calapuja, Department of Puno, Peru. • A - paratypes CPI-7011a-k; B - paratypes CPI-7012a-b; C - holotype CPI-7013a (middle specimen) paratypes CPI-7013b-c; D - young specimens encrusting a dorsal valve of Colaptomena expansa expansa (Sowerby, 1839), CPI-7014. $\bullet$ E, F-Cornulites vilcae sp. nov. from the Sandbian (?Calapuja Formation) of Punco Punco creek, ca $4.5 \mathrm{~km}$ northwest from the city of Ayaviri, Department of Puno, Peru; E - holotype CPI-7027a (right) and paratype CPI-7028b (left). Scale bars are $5 \mathrm{~mm}$. All specimens are latex casts derived from external moulds.

Silurian cornulitids from carbonate facies. Alternatively, in decalcified siliciclastic rocks, cornulitids may not be so easily noticed when encrusting brachiopods etc. singly; however, aggregations of tubes will be much more conspicuous. Secondarily free forms and aggregative forms have not been described from carbonate platform sediments of Sandbian of Baltica. Thus, it is possible that cornulitids in siliciclastic basins may have had more diverse life modes. In one case brachiopod shell was likely encrusted post mortem indicated by lack of orientation among encrusting cornulitids. However, multiple oriented cornulitids on a strophomenid brachiopods (externally) likely represent a syn vivo encrustation (Fig. 2D), but no brachiopod shell malformations occur near cornulitids. In the latter case the Cornulites zatoni sp. nov. could have taken advantage of inhalant or exhalant currents produced by the host brachiopod (Schumann 1967, Richards 1974).

\section{Paleobiogeography}

Localities on the Mediterranean margin of Gondwana are widely accepted to have been positioned in high latitudes during most of the Ordovician (Harper et al. 2013). In contrast, the Laurentian, Kazakh, northern Chinese and Eastern Gondwanan localities were situated in the tropics 
(Harper et al. 2013). The Proto-Andean Margin of Gondwana (i.e. Peru) was situated at intermediate latitude during the early Late Ordovician (Villas et al. 2015). Avalonia and Baltica were located at a similar latitude in the Sandbian, and several "Celtic" brachiopod species have been identified recently in the typically Gondwanan assemblage of the Calapuja Formation (Villas et al. 2015). Thus, it is interesting that the cornulitids from the Sandbian of Peru are different from those known from the Sandbian of Baltica (Vinn 2013) and the Late Ordovician of Avalonia (Schlotheim 1820, Murchison 1839). However, Cornulites vilcae sp. nov. resembles somewhat $C$. scalaris from the Late Ordovician of Britain and Spain, although this alone does not prove a connection between the cornulitid faunas of Peru, Britain and Spain. It is possible that the distribution of cornulitids could have been controlled more by palaeogeographical distance than by latitude. Surprisingly, Cornulites zatoni sp. nov from Sandbian of Peru resembles closely a Cornulites species (Hall 1888) from the Late Ordovician of North America (Laurentia). The probable occurrence of Cornulites zatoni sp. nov. in the Late Ordovician of North America could indicate that some cornulitid taxa had wide paleogeographical distributions and could dwell in different climates.

\section{Acknowledgements}

The authors express their gratitude to César Chacaltana (INGEMMET, Lima), for field assistance and his work on the palaeontological collections from the Peruvian Geological Survey; and Carlos Alonso (Complutense University, Madrid) who made the photographs of the specimens. Financial support to O.V. was provided by a Palaeontological Association Research Grant and Estonian Research Council projects ETF9064 and IUT20-34. The fieldwork of J.C.G.-M. was supported by IBEROR project (ref. CGL2012-39471/BTE) of the Spanish Ministry of Economy and Competitiveness. This paper is also a contribution to the IGCP project 591 (IUGS-UNESCO, "The Early to Middle Palaeozoic Revolution”). We are grateful to Paul D. Taylor (Natural History Museum, London) and an anonymous reviewer for the constructive reviews.

\section{References}

BARRANDE, J. 1867. Systême silurien du centre de la Bohême. lère Partie: Recherches Paléontologiques. Vol. III. Texte et 16 Planches. Classe des Mollusques. Ordre des Ptéropodes. xv + 179 pp. Chez l'auteur et éditeur, Prague.

Bergström, S.M., Chen, X., Gutiérrez -Marco, J.C. \& Dronov, A. 2009. The new chronostratigraphic classification of the Ordovician System and its relations to major regional series and stages and to $\delta^{13} \mathrm{C}$ chemostratigraphy. Lethaia 42, 97-107. DOI 10.1111/j.1502-3931.2008.00136.x

Bond, D. 2006. The fate of the homoctenids (Tentaculitoidea) during the Frasnian-Famennian mass extinction (Late Devonian). Geobiology 4, 167-177.

DOI 10.1111/j.1472-4669.2006.00078.x

BouČEK, B. 1964. The tentaculites of Bohemia. 125 pp. Publication of Czechoslovakian Academy of Sciences, Prague.

Cowper Reed, F.R. 1923. New fossils from Girvan. Geological Magazine 60, 268-276.

DOI $10.1017 /$ S0016756800085770

Chacaltana, C., GutiérRez-Marco, J.C., RÁbano, I. \& GarcíaBellido, D. 2010. Descubrimiento de cornulítidos y otros raros invertebrados ordovícicos en el Altiplano peruano. Sociedad Geológica del Perú, Publicación Especial 9, 213-216.

Díaz-Martínez, E., Acosta, H., CÁrdenas, J., Carlotto, V. \& RodríguEZ, R. 2001. Paleozoic diamictites in the Peruvian Altiplano: evidence and tectonic implications. Journal of South American Earth Sciences 14, 587-592.

DOI 10.1016/S0895-9811(01)00054-2

FISHER, D.W. 1962. Small conoidal shells of uncertain affinities, 130-143. In Moore, R.C. (ed.) Treatise on Invertebrate Paleontology, Part W. Geological Society of America \& University of Kansas Press, Lawrence.

Gutiérrez-Marco, J.C., Carlotto, V., Monge, R., Chacaltana, C. \& CÁrdenAS, J. 2010. Problemática de la Formación Sandia (Ordovícico) en la Cordillera Oriental peruana: ¿una o varias unidades de distinta edad? Sociedad Geológica del Perú, Publicación Especial 9, 853-857.

Hall, J. 1847. Paleontology of New York, Volume 1, Containing descriptions of the organic remains of the lower division of the New York System. 338 pp. Van Benthuysen, Albany.

Hall, J. 1888. Tubicolar Annelida. Natural History of New York; Palaeontology. Volume 7.278 pp. Geological Survey, Albany, New York.

Harper, D.A.T., Rasmussen, C.M.Ø., Liljeroth, M., Blodgett, R.B., Candela, Y., Jin, J., Percival, I.G., Rong, J.-Y., Villas, E. \& ZHAN, R.-B. 2013. Biodiversity, biogeography and phylogeography of Ordovician rhynchonelliform brachiopods, 127-144. In Harper, D.A.T. \& Servais, T. (eds) Early Palaeozoic Biogeography and Palaeogeography. Geological Society of London, Memoirs 38.

Klink, B.A., Ellison, R.A. \& Hawkins, M.P. 1986. The geology of the Western Cordillera and Altiplano west of Lake Titicaca, southern Peru. 353 pp. Unpublished Report of the Overseas Division, British Geological Survey.

LAUBACHER, G. 1977. Géologie des Andes peruviennes. Géologie de l'Altiplano et de la Cordillère Orientale au nord et nord-ouest du lac Titicaca (Pérou). 117 pp. PhD thesis, Université des Sciences et Techniques du Languedoc, Académie de Montpellier.

LAUBACHER, G. 1978. Estudio geológico preliminar de la Cordillera Oriental. III. Estudio geológico del Bloque C, Dpto. Puno. 89 pp. Office de la Recherche Scientifique et Technique Outre Mer (ORSTOM) and Servicio de Geología y Minería (SGM), Lima.

Meek, F.B. \& Worthen, A.H. 1865. Descriptions of New Crinoidea, etc., from the Paleozoic Rocks of Illinois and some adjoining States. Proceedings of Philadelphia Academy of Natural Sciences, 1-155.

Meneghini, G. 1857. Paléontologie de l'île de Sardaigne ou de- 
scription des fossiles recueillis dans cette contrée par le Géneral Albert de La Marmora, p. 90. In De La Marmora, A. Voyage en Sardaigne. Troisième Partie. Géologie. Les Frères Bocca, Libraires du Roi \& Arthus Bertrand, Turin \& Paris.

Murchison, R.I. 1854. Siluria. 523 pp. John Murray, London.

Palacios, O., De la Cruz, J., De la Cruz, N., Klink, B.A., Allison, R.A. \& Hawkins, M.P. 1993. Geología de la Cordillera Occidental y Altiplano al oeste del Lago Titicaca - sur del Perú (Proyecto Integrado del Sur). Boletín del Instituto Geológico Minero y Metalúrgico, Serie A (Carta Geológica Nacional) 42, 1-257.

Prantl, F. 1948. The genus Conchicolites Nicholson, 1872 (Serpulimorpha) in the Ordovician of Bohemia. Věstník Královské české společnosti nauk, Třída matematicko-prrírodovědecká 1948-9, 1-7.

RichaRds, P.R. 1974. Ecology of the Cornulitidae. Journal of Paleontology 48, 514-523.

Schumann, D. 1967. Die lebenweise von Mucrospirifer Grabau, 1931 (Brachiopoda). Palaeogeography, Palaeoclimatology, Palaeoecology 4, 29-285.

SChLOtheim, E.F. 1820. Die Petrefaktenkunde auf ihrem jetzigen Standpunkte durch die Beschreibung seiner sammlung versteinerter und fossiler Überreste des Thier- und Planzenreichs erläutert. 437 pp. Becker'sche Buchhandlung, Gotha.

Sowerby, J. DE C. 1839. Fossil shells of the lower Ludlow age, 579-712. In Murchison, R.I. (ed.) The Silurian System, founded on geological researches in the counties of Salop, Hereford, Radnor, Montgomery, Caermarthen, Brecon, Pembroke, Monmouth, Gloucester, Worcester, and Stafford; with descriptions of the coalfields and overlying formations. John Murray, London.

Spano, C. 1974. Tentaculita dell'Ordoviciano della Sardegna. Rendiconti del Seminario della Facoltà di Scienze dell'Università di Cagliari 44, 187-204.

TAYLOR, P.D. \& WILson, M.A. 2003. Palaeoecology and evolution of marine hard substrate communities. Earth Science Reviews 62, 1-103. DOI 10.1016/S0012-8252(02)00131-9

Verneuil, E. DE \& Barrande, J. 1855. Descriptions des fossiles trouvés dans les terrains silurien et dévonien d'Almaden, d'une partie de la Sierra Morena et des montagnes de Tolède.
Bulletin de la Société Géologique de France [2 ${ }^{e}$ série] 12, 964-1025.

Villas, E., Colmenar, J. \& Gutiérrez-Marco, J.C. 2015. Late Ordovician brachiopods from Peru and their palaeobiogeographical relationships. Palaeontology 58, 455-487.

DOI 10.1111/pala.12152

Vinassa de Regny, P. 1927. Fossili ordoviciani sardi, parte I. Memoire della Regia Accademia Nazionale dei Lincei, Classe di Scienze Fisiche 2, 437-496.

VinN, O. 2010. Adaptive strategies in the evolution of encrusting tentaculitoid tubeworms. Palaeogeography, Palaeoclimatology, Palaeoecology 292, 211-221. DOI 10.1016/j.palaeo.2010.03.046

VINN, O. 2013. Cornulitid tubeworms from the Ordovician of eastern Baltic. Carnets de Géologie 13, 131-138. DOI 10.4267/2042/51214

Vinn, O. \& Mutvei, H. 2009. Calcareous tubeworms of the Phanerozoic. Estonian Journal of Earth Sciences 58, 286-296. DOI 10.3176/earth.2009.4.07

WitTMER, J.M. \& Miller, A.I. 2011. Dissecting the global diversity trajectory of an enigmatic group: The paleogeographic history of tentaculitoids. Palaeogeography, Palaeoclimatology, Palaeoecology 312, 54-65.

DOI 10.1016/j.palaeo.2011.09.009

ZATON, M. \& BoRsZCZ, T. 2013. Encrustation patterns on post-extinction early Famennian (Late Devonian) brachiopods from Russia. Historical Biology 25, 1-12.

DOI 10.1080/08912963.2012.658387

Zatoń, M., Hagdorn, H. \& Borszcz, T. 2014. Microconchids of the species Microconchus valvatus (Münster in Goldfuss, 1831) from the Upper Muschelkalk (Middle Triassic) of Germany. Palaeobiodiversity and Palaeoenvironments 94, 453-461. DOI 10.1007/s12549-013-0128-6

ZAtoŃ, M., VinN, O. \& Tomescu, M. 2012. Invasion of freshwater and variable marginal marine habitats by microconchid tubeworms - an evolutionary perspective. Geobios 45, 603-610. DOI 10.1016/j.geobios.2011.12.003

ZHAN, R.-B. \& VINN, O. 2007. Cornulitid epibionts on brachiopod shells from the Late Ordovician (middle Ashgill) of East China. Estonian Journal of Earth Sciences 56, 101-108. 